\title{
DAMPAK PENGAJIAN KEAGAMAAN DALAM MEMBINA AKHLAK PEMUDA DI NEGERI MORELLA KECAMATAN LEIHITU KABUPATEN MALUKU TENGAH
}

\author{
Ade Irmalia Waulath, ${ }^{1}$ St. Jumaeda, ${ }^{2}$ Nur Khozin ${ }^{2}$ \\ ${ }^{1}$ Mahasiswa PAI FITK IAIN Ambon, ${ }^{2}$ Dosen PAI FITK IAN Ambon \\ irmaamboon2019@gmail.com
}

\begin{abstract}
Abstrak; hasil penelitian menunjukan bahwa pelaksanaan pengajian keagamaan di negeri Morella yang diprogramkan oleh kepala pemuda ini telah berlangsung 2 tahun lamanya yang telah memberikan dampak dan pengaruh yang besar dalam kehidupan pemuda negeri Morella, baik dalam bidang spritual berupa sudah mulai adanya kesadaran dari para pemuda dalam menjalankan ajaran agamanya, kemudian, bidang sosial berupa sudah mulai adanya hubungan yang baik dengan masyarakat, serta pengaruhnya terhadap psikologi berupa sudah mulai membaik karakter para pemuda. Oleh karena itu, pelaksanaan pengajian keagamaan ini dapat dikatakan mempunyai andil besar dalam perubahan dan pembinaan akhlak pemuda, walaupun masih terbilang muda, namun pengajian ini mampu menunjukan eksistensinya. Hal ini tidak terlepas dari dukungan yang diberikan dari semua pihak, dimulai dari adanya dukungan dari pemerintah setempat, adanya kesadaran diri dari para pemuda, adanya dukungan dari orang tua, kesabaran dari para pengajar dan fasilitas yang disediakan. Meskipun demikian, pengajian keagamaan juga tidak terlepas dari kendala-kendala yang datang, entah itu masalah mengajak pemuda, anggaran, kurangnya pengajar, manajemen yang kurang baik, kurangnya metode yang digunakan, tidak adanya evaluasi, dan pengaruh teknologi
\end{abstract}

Kata Kunci: Dampak Pengajian Keagamaan, Membina Akhlak Pemuda

\begin{abstract}
: the results showed that the implementation of religious studies in the country of Morella which was programmed by the head of this young man had been going on for 2 years which had a great impact and influence in the life of the youth of the country of Morella, both in the spiritual field in the form of having begun to realize the awareness of the youth in carrying out the teachings His religion, then, in the form of social fields has begun to have a good relationship with the community, and its influence on psychology in the form has begun to improve the character of the youth. Therefore, the implementation of this religious study can be said to have a big contribution in the change and fostering of the morals of youth, although still relatively young, but this study is able to show its existence. This is inseparable from the support given from all parties, starting from the support of the local government, the self-awareness of the youth, the support of parents, patience from the teachers and the facilities provided. Even so, religious study is also inseparable from the obstacles that come, whether it's a matter of inviting youth, budget, lack of teachers, poor management, lack of methods used, lack of evaluation, and the influence of technology
\end{abstract}

Keywords: The Impact of Religious Recitation, Fostering Youth Morals

\section{PENDAHULUAN}

Zaman yang semakin maju dan modern ini memicu timbulnya krisis akhlakul karimah. Dimana sudah mulai merosotnya akhlak yang ditandai dengan mulai berkurang dan telah menyimpang dari ajaran-ajaran agama baik di kalangan masyarakat maupun di kalangan pemuda. Salah satu penyebab timbulnya krisis akhlakul karimah yang terjadi saat ini dikarenakan orang sudah mulai lengah dan kurang mengindahkan agama, khususnya di kalangan 
Pemuda yang identik dengan kehidupan bebas. Sikap mementingkan diri sendiri, egois, hedonisme serta pudarnya nilai-nilai sopan santun semakin lemah dalam diri manusia, dan pemuda khususnya dengan kehidupan bebasnya.

Fenomena krisis akhlak pada pemuda ini semakin dirasakan oleh masyarakat khususnya di Provinsi Maluku, sebagai salah satu Provinsi yang dikenal dengan keanekaragaman agama atau multikultural. di Ambon sendiri. kemerosotan akhlak ini terjadi bukan hanya di daerah perkotaan namun juga terjadi di salah satu negeri yang jauh dari ibu kota yaitu di negeri Morella Kecamatan Leihitu Kabupaten Maluku Tengah.

Dalam kehidupan sehari-hari di negeri Morella banyak pemuda yang dalam berperilaku dan bergaul sudah jauh dari ajaran dan nilai-nilai sosial dan agama Islam. Krisis akhlak pemuda ini terjadi bukan hanya sesama teman sebaya akan tetapi juga terjadi terhadap orang tua dan masyarakat. Misalkan ketika mereka berbicara dan bergaul dengan sesama teman sebaya dan masyarakat, mereka sering menggunakan bahasa tidak sopan dan cenderung berbicara dengan bahasa kasar yang memang tidak pantas diucapkan baik terhadap teman maupun masyarakat. Selain itu, seringkali mengabaikan perintah ataupun larangan orang tua.

Kemerosotan akhlak pemuda di negeri Morella, disebabkan oleh beberapa faktor, diantaranya rendahnya pendidikan orang tua baik itu pendidikan umum maupun pendidikan agama Islam.Yang mayoritas hanya mengecap pendidikan sampai tingkat Sekolah Menengah Atas (SMA), penyebab selanjutnya adalah tuntutan ekonomi yang semakin hari semakin banyak dibutuhkan. Penyebab lain kenakalan pemuda juga dikarenakan pesatnya perkembangan teknologi yang memudahkan bagi pemuda untuk mengakses berbagai informasi.

\section{METODE}

Metode yang digunakan dalam penelitian ini adalah metode deskriptif analisis dengan pendekatan kualitatif. Metode ini pada dasarnya bertujuan untuk memahami keadaan yang saling berhubungan antara berbagai gejala eksternal maupun internal yang terdapat dalam kehidupan sosial masyarakat, khususnya di negeri Morella Kecamatan Leihitu Kabupaten Maluku Tengah (Lexi J. Moleong, 2002). Penelitian kualitatif sebagai prosedur pengumpulan data yang meghasilkan data berupa observasi, wawancara dan dokumentasi, dalam hal ini tentang bagaimana dampak pengajian keagamaan dalam membina akhlak pemuda, dalam pelaksanaanya di lapangan, peneliti berusaha memahami fenomena yang terjadi dengan sikap yang disesuaikan dengan keseharian dengan tanpa menjaga jarak dengan informan. sehingga pengambilan data, baik dari dukumen, wawancara dengan informan dan pengamatan berjalan dengan baik. adapaun lokasi penelitian ini dilaksanakan di Provinsi Maluku tepatnya di Negeri Morella Kecamatan Leihitu Kabupaten Maluku Tengah.

\section{HASIL}


Berkembangnya teknologi seperti internet bukan lagi dimanfaatkan untuk hal-hal yang positif, namun juga digunakan untuk hal-hal yang negatif. Berdasarkan pengamatan peneliti, di negeri Morella Kecamatan Leihitu, banyak fenomena yang terjadi salah satunya penggunaan media internet, para pemuda yang biasanya berkumpul di warung kopi mangga dua untuk mengakses internet yang berbau pornografi. selain itu permainan (ludo game) yang ada pada Handpone mereka sering dijadikan sebagai alat untuk bermain judi.

Fenomena ini jika dibiarkan takutnya akan menjadi hal yang biasa dan yang paling disayangkan adalah pengaruh negatif hal tersebut merambah kepada anak-anak yang masih duduk di sekolah SD/MI.

Menurut Norvan, kenakalan remaja dan fenomena Anak Baru Gede (ABG) sekarang bisa terjadi karena tiga hal: Pertama, Remaja adalah kelompok masyarakat yang paling banyak jumlahnya dibanding kelompok lain. Oleh karena itu jika kelompok yang banyak ini berada dalam kondisi moral yang membahayakan nasib dan masa depannya, akibatnya bukan hanya bagi kelompoknya saja tetapi bagi bangsa dan Negara. Kedua, Para remaja secara psikologis termasuk kelompok yang paling mudah mendapatkan pengaruh, jiwanya mudah bergolak, sebagai akibat pribadinya belum terbentuk. Ketiga, Setiap manusia mesti mengalami masa remaja. Dengan demikian, persoalan remaja atau ABG adalah persoalan bersama atau persoalan umat manusia. Karena itu, perlu mendapatkan perhatian kita semua. Saat ini orang tua misalnya merasakan bahwa salah satu masalah berat yang dihadapi kedua orang tua adalah bagaimana menyelamatkan anaknya melampaui masa remaja dan kepemudaannya (Norvan Ardy dan Barnawi, 2012).

Salah satu upaya yang dilakukan oleh staf pemerintah negeri Morella untuk mengatasi hal ini adalah menghidupkan pengajian-pengajian disetiap komplek-komplek dan Mushola karena dalam pengajian bukan hanya diajarkan keterampilan saja, tetapi ada juga siraman rohani dan nasehat tentang bagaimana cara berakhlak terhadap orang tua dan masyarakat. Sejalan dengan upaya tadi, kepala pemuda negeri Morella (Ujailin Latukau) bersama staf pemerintahan negeri Morella melaksanakan program pengajian pada bulan Ramadhan pasca dilantiknya, program ini dilaksanakan setelah ba'da isya dan berlaku diseluruh kompleks yang ada di negeri Morella.

Program yang dicanangkan ini telah berlangsung selama kurang lebih dua tahun, yang hanya diselenggarakan di dua komplek saja yakni Karamat Indah dan Salatiga. Pengajian ini biasanya diikuti oleh pemuda dan remaja yang dipimpin oleh seorang ustadz/imam (Observasi, 2018).

Namun pada kenyataannya masih banyak perilaku pemuda di negeri ini yang masih jauh dari nilai-nilai Islam walaupun sebagian mereka mengikuti pengajian. Dari latar belakang di atas penulis tertarik mengkaji lebih lanjut mengenai "Dampak pengajian keagamaan dalam membina akhlak pemuda di negeri Morella Kecamatan Leihitu Kabupaten Maluku Tengah".

\section{PEMBAHASAN}


Pengajian berasal dari kata dasar "kaji" yang berarti pelajaran (terutama dalam hal agama). Yang selanjutnya pengajian adalah: Ajaran dan pengajaran, pembacaan al-Qur'an (Depdikbud, 1998). Kata pengajian itu terbentuk dengan adanya awalan "pe" dan akhiran "an" yang memiliki dua pengertian: pertama sebagai kata kerja yang berarti pengajaran, yakni pengajaran-pengajaran ilmu agama Islam, dan ke-dua sebagai kata benda yang menyatakan tempat, yaitu tempat untuk melaksanakan pengajaran agama Islam, yang dalam pemakaiannya banyak istilah yang digunakan, seperti pada masyarakat sekarang dikenal dengan majlis ta'lim (Ensiklopedia Islam, 1997). Pengajian adalah lembaga pendidikan Islam non formal yang memiliki kurikulum tersendiri, diselenggarakan secara berkala dan teratur, dan. diikuti oleh jama'ah yang relatif banyak, dan bertujuan untuk membina dan mengembangkan hubungan manusia yang santun dan serasi antara sesamanya, dan antara manusia dengan lingkungannya, dalam rangka membina masyarakat yang bertaqwa kepada Allah SWT (Nurul Huda, 1990). Berarti pengajian merupakan kegiatan pendidikan agama Islam bukan hanya terbatas pada pengajian alQur'an saja, tetapi pengajian di sini termasuk juga pengajian pendidikan agama Islam secara umum, baik itu pengajian tentang tauhid, ibadah, fiqih, hadits dan kajian ilmu agama Islam lainnya yang juga mempunyai fungsi dan tujuan tertentu.

Pembinaan adalah proses, perbuatan, cara membina, pembaharuan, penyempurnaan, usaha, tindakan, dan kegiatan yang dilakukan secara berdaya guna dan berhasil guna untuk memperoleh hasil yang lebih baik (Muhammad Azmi, 2006). Menurut bahasa (etimologi) perkataan "akhlak" ialah bentuk jama' dari khuluq (khuluqun) yang berarti budi pekerti, perangai, tingkah laku, atau tabiat. Akhlak disamakan dengan kesusilaan, sopan santun. Khuluq merupakan gambaran sifat batin manusia, gambaran bentuk lahiriyah manusia. Seperti raut wajah, gerak anggota badan dan seluruh tubuh (Yatimin Abdullah, 2007).

\section{Macam-Macam Akhlak}

Secara garis besar akhlak dapat dibedakan atas dua macam yaitu:

1) Akhlak baik (Akhlakul Mahmudah) adalah tingkah laku terpuji yang merupakan ada kesempurnaan iman seseorang kepada Allah, Akhlakul karimah dilahirkan berdasarkan sifat-sifat yang terpuji. Akhlak yang baik (terpuji) atau akhlak mahmudah yaitu akhlak yang senantiasa berada dalam kontrol ilahiyah yang dapat membawa nilai-nilai positif dan kondusif bagi kemaslahatan umat, seperti sabar, jujur, bersyukur, tawadhu (rendah hati) dan segala yang sifatnya baik.

2) Akhlak tercela atau tidak baik (Akhlakul Mudzmumah) adalah perangai yang tercermin dari tutur kata, tingkah laku, dan sikap yang tidak baik. Akhlak tidak baik akan menghasilkan pekerjaan buruk dan tingkah laku yang tidak baik. Akhlak yang tidak baik (tercela) atau akhlak madzmumah adalah akhlak yang tidak dalam kontrol ilahiyah, atau berasal dari hawa nafsu yang berada dalam lingkaran syaitaniyah dan dapat membawah suasana negatif serta destruktif 
bagi kepentingan umat manusia, seperti takabur (sombong), berkhianat, tamak, pesimis, malas dan lain-lain.

\section{Dampak Pengajian Keagamaan dalam Membina Akhlak Pemuda di Negeri Morella Kecamatan Leihitu Kabupaten Maluku Tengah}

Pengajian merupakan suatu kegiatan keagamaan yang di dalamnya terdapat bimbingan pengajaran tentang masalah keagamaan. Biasanya dalam pelaksanaan pengajian ini dilakukan baik secara perorangan maupun secara kelompok, dalam rangka mewujudkan manusia yang sadar akan nilainilai agama. Pengajian yang penulis maksudkan dalam pembahasan ini adalah dampak pengajian keagamaan dalam membina akhlak pemuda di negeri Morella Kecamatan Leihitu Kabupaten Maluku Tengah. Pelaksanaan pengajian keagamaan ini merupakan salah satu prograbidang kerohanian yang dicanangkan oleh kepala pemuda dan stafnya pasca dilantiknya beliau. Berdasarkan kesepakatannya pengajian ini diberlakukan untuk semua komplek yang ada, namun yang masih berjalan sampai sekarang hanya dua komplek, yakni Keramat Indah dan Salatiga. pengajian ini telah berlangsung 2 tahun lamanya yang pelaksanaannya dari malam senin-jumat, yang dilakukan setelah ba'da isya, namun waktunya bisa saja berubah tergantung dengan kesepakatan maupun kepentingan bersama. Dalam pelaksanaannya pengajian ini biasanya dilaksanakan dari pukul 20.30 WIT sampai selesai, yang memerlukan waktu satu jam, terkadang berlangsung kurang dari satu jam hal ini disebabkan oleh beberapa hal misalnya: adanya kegiatan bersama lainnya dalam masyarakat maupun jika ustadz tidak bisa menghadiri pengajian atau akan datang terlambat, maka ustadz akan memberikan tanggung jawab sementara kepada santri yang lebih pandai untuk menggantikannya mengajar sampai waktu yang ditentukan. Selain itu dalam pelaksanaan pengajian keagamaan di negeri Morella mempunyai tujuan untuk meningkatkan keimanan dan ketaqwaan kepada Allah SWT, menanamkan nilai ajaran Islam dan membentuk pemuda yang berakhlak mulia, yang berpedoman pada dasar dan sumber ajaran Islam yaitu al-Qur'an dan Hadist, di mana kedua sumber tersebut merupakan sebuah rujukan bagi umat Islam dalam menghadapi kehidupan dan permasalahan yang terjadi. Terlepas dari tujuan yang ingin dicapai dalam pelaksanaan pengajian keagamaan ini, yang paling terpenting adalah proses pelaksanaan pengajian itu sendiri, karena seperti yang kita ketahui proses yang baik akan memberikan hasil yang baik pula. Sebagai sebuah program, ada faktor-faktor yang saling berkaitan dan tidak bisa dilepas pisahkan antara satu dengan yang lainnya, dan pada akhirnya akan menentukan hasil dari tujuan yang ingin dicapai dalam pengajian. Sebagaimana hasil penelitian yang peneliti 
dapatkan bahwa meskipun masih seumur jagung pembentukan program pengajian ini, namun pengajian ini mampu menunjukan pengaruh dan dampak yang bisa dirasakan sehingga memberikan efek yang positif, entah itu pengaruh dalam diri pemuda sendiri maupun bagi masyarakat. Dalam kenyataannya bahwa dampak yang dirasakan dalam pelaksanaan pengajian ini bervariasi, dimulai dari dampak Spritual, seperti diketahui bahwasannya dalam masalah spritual ini berkaitan dengan hubungan manusia dengan Tuhan-Nya (Habluminnaulah). Pemuda yang mengikuti pengajian mengaku telah merasakan adanya kedekatan dengan sang pencipta, sehingga dalam pelaksanaan pengajian keagamaan ini sudah ada keikhlasan dan kesadaran diri dari para pemuda untuk mengikuti pengajian, kemudian adanya dampak sosialogi yang dirasakan entah itu hubungan pemuda dengan masyarakat, maupun dengan lingkungan sekitarnya, hal ini terbukti berdasarkan hasil pengamatan dan wawancara dengan narasumber, dan yang terakhir adalah adanya dampak psikologi yang dirasakan oleh pemuda. Menurut pengakuan dari pemuda bahwasnya setelah mengikuti pengajian mereka merasakan adanya kenyamanan dan ketentraman jiwa. Hal ini mengisyarakatkan bahwa program pengajian ini mempunyai andil yang besar dan pengaruhnya bagi masyarakat Morella terkhususnya para pemuda.

\section{Faktor Pendukung dan Penghambat dalam Pengajian Keagamaan di Negeri Morella Kecamatan Leihitu Kabupaten Maluku Tengah.}

Untuk mewujudkan suatu proses yang baik, diperlukan adanya kesadarandan kerjasama yang baik dari semua komponen atau orang-orang yang terlibat di dalamnya baik secara langsung maupun tidak langsung dalam proses pelaksanaan pengajian keagamaan ini.Seperti halnya program yang lain, pasti saja mengalami banyak hambatan dan rintangan. Sama halnya yang dirasakan dalam pengajian ini, meskipun demikian. Kenyataannya dalam pelaksanaan pengajian keagamaan ini juga mempUnyai fakor pendukung, sehingga pelaksanaan pengajian ini dapat berjalan sampai dengan sekarang oleh sebab itu, dukungan dari dari semua pihak penting dalam pelaksanaan pengajian keagamaan, sehingga dapat mewujudkan tujuan yang hendak dicapai. Hal ini mengisyaratkan bahwa pelaksanaan program pengajian ini mampu menujukan eksistensinya terlebih lagi dengan adanya dukungan dari pemerintah dan tokoh masyarakat yang ditunjukan dengan adanya kesabaran dan keikhlasan dalam membuat program pengajian tetap berjalan.Fakta yang terjadi dilapangan berdasarkan hasil pengamatan dan informasi yang didapat bahwasannya peneliti melihat adanya dukungan yang diberikan dari semua pihak yang terlibat baik itu dukungan moril berupa dukungan dan motivasi yang diberikan dari pengajar, 
orang tua santri maupun santri sendiri, sedangkan dukungan material yang diberikan berupa adanya penyediaan fasilitas dari kepala pemuda dan stafnya, seperti tempat pengajian, al-Qur'an, papan tulis, spidol, penghapus, dan sarana pengdukung lainnya. Selain itu juga adanya kesabaran dan keikhlasan dari para pengajar dalam membagi waktu dan tenaga untuk memberikan pengetahuannya. Dan yang paling terpenting adalah adanya kesadaran dan kemauan dari pemuda untuk mengikuti pengajian. Terlepas dari dukungan yang didapat, dalam pelaksanaan program pengajian ini juga mempunyai hambatan yang bervariasi, diantaranya, mengajak para pemuda untuk mengikuti pengajian, keterbatasan anggaran yang ada, kurangnya pengajar, pengaruh teknologi, kurangnya metode yang digunakan, manajemen yang kurang baik, namun yang paling penting bahwa tidak adanya evaluasi.

\section{PENUTUP}

Bertolak dari uraian-uraian pada bab-bab di atas maka penulis dapat menarik kesimpulan sebagai berikut:

1. Pengajian keagamaan dalam membina akhlak pemuda di negeri Morella Kecamatan Leihitu Kabupaten Maluku Tengah. Yang bertempat di musholah atau tempat-tempat yang telah ditetapkan yang dilaksankan setiap malam dari hari senin-jumat setelah sholat isya. Pengajian keagamaan di negeri Morella ini berdasarkan kesepakatan yang dibuat dan merupakan program yang dicanangkan oleh kepala pemuda pasca di lantiknya beliau. Tujuan pelaksanaan pengajian keagamaan ini untuk meningkatkan keimanan dan ketaqwaan kepada Allah SWT, menanamkan nilai ajaran Islam dan membentuk pemuda yang berakhlak mulia. Materi yang diberikan dalam pengajian ini mengenai pengajaran agama Islam diantaranya, akidah, tauhid, ibadah, fiqih, dan al-Qur'an dan tajwid. Metode yang digunakan dalam pengajian ini meliputi Metode iqra dan tadarus. Dalam pelaksanaan pengajian ini juga mempunyai pengaruh yang besar dalam kehidupan pemuda, meskipun baru seumur jagung, namun pengajian keagamaan ini menunjukan eksistensinya. Terbukti dengan adanya pengajian ini sudah dapat dirasakan pengaruh dan dampaknya dalam kehidupan pemuda, meliputi dampak spritual, sosial, dan psikologi pemuda. Ini mengisyaratkan bahwa walaupun pengajian ini baru seumur jagung dalam pelaksanaannya namun dapat memberikan andil yang besar dalam kehidupan masyarakat negeri Morella.

2. Faktor pendukung dalam pelaksanaan pengajian keagamaan di negeri Morella adalah adanya perhatian dari tokoh masyarakat, tokoh agama, dan tokoh-tokoh lainnya, motivasi dari dalam diri pemuda, dan fasilitas yang cukup memadai, sedangkan faktor penghambat dalam pengajian keagamaan yaitu mengajak para pemuda, kurangnya pengajar atau tenaga kependidikan, masalah anggaran, manajemen yang kurang baik, 
kurangnya metode yang digunakan, dan pengaruh teknologi serta tidak adanya evaluasi.

\section{DAFTAR PUSTAKA}

[1] Moleong, Lexi J. M.A Metode Penelitian Kualitatif, PT. Pemuda Risdakarya 2000.

[2] Tim Penyusun Kamus Pusat Pembinaan Bahasa Indonesia Depdikbud, Kamus Besar Bahasa Indonesia, Cet. Ke-1, Jakarta: Balai Pustaka, 1998.

[3] Dewan Redaksi Ensiklopedia Islam, Ensiklopedia Islam, cet. Ke-4, Jilid 3, Jakarta: Iktiar Baru Van Hoeve, 1997.

[4] Nurul Huda, Pedoman Majlis Taklim, Jakarta: KODI, 1990.

[5] Muhammad Azmi, Pembinaan Akhlak Anak Usia Pra Sekolah, Yogyakarta: Belukur, 2006.

[6] Abdullah, Yatimin. Studi Akhlak dalam Perspektif Al-Qur'an, Jakarta: Amzah, 2007.

[7] Pelupessy, Nur Khozin Abdullah, and Saddam Husein. "PEMBINAAN AKHLAK MULIA MAHASISWA DALAM LEMBAGA DAKWAH KAMPUS (LDK) AL-IZZAH IAIN AMBON." al-IItizam: Jurnal Pendidikan Agama Islam 3.1 (2018): 53-64.

[8] Nata, Abuddin Akhlak. Tasawuf, Jakarta: Rajawali Pers, 2009.

[9] Ihsan Sanusi, Kasmuri Selamat. Akhak Tasawuf ,(Jakarta: Kalam Mulia, 2012.

Husein, Saddam. "URGENSI PEMBELAJARAN AL-QUR'AN

[10] HADIST TERHADAP PRESTASI BELAJAR PESERTA DIDIK DI MTs NURUL IKHLAS KALAPA DUA SERAM BAGIAN BARAT." al-Iltizam: Jurnal Pendidikan Agama Islam 3.1 (2018): 1-13. 